\title{
Molecular Characterization of Organic Nitrogen in Cattle Manure Compost by Size-Exclusion HPLC with Chemiluminescent Nitrogen Detection
}

\author{
Toshiro Matsunaga, ${ }^{* \dagger}$ Mihoko Morizumi,* and Tsunenori Kameda** \\ *Agricultural Research Center, National Agriculture and Food Research Organization, Tsukuba, \\ Ibaraki 305-8666, Japan \\ **National Institute of Agrobiological Sciences, Tsukuba, Ibaraki 305-8634, Japan
}

\begin{abstract}
To characterize organic nitrogen present in cattle manure compost, a hot-water extract of the compost along with an acid-insoluble (humic acid-like) fraction either treated with alkali or laccase or untreated were separated by size-exclusion high-performance liquid chromatography (SE-HPLC). Nitrogen was then detected by chemiluminescent nitrogen detection (CLND), and humic acid-like substances were detected by measuring the absorbance at $420 \mathrm{~nm}$. The acid-insoluble fraction comprised the higher molecular-weight region in the chromatogram of the whole extract, and its chromatogram pattern of CLND was similar to that of the absorbance at $420 \mathrm{~nm}$. Changes in the molecular-weight distribution of the acid-insoluble fraction detected by CLND due to alkaline degradation and laccase polymerization were in agreement with those observed by measuring the absorbance at $420 \mathrm{~nm}$. These results, together with other data, demonstrate that protein and humic acid-like moieties are present in the same molecule in compost organic matter.
\end{abstract}

Keywords Organic nitrogen, cattle manure compost, humic substance, size-exclusion HPLC, chemiluminescent nitrogen detection

(Received June 18, 2013; Accepted July 29, 2013; Published September 10, 2013)

\section{Introduction}

Animal manure compost can be used as a nitrogen $(\mathrm{N})$ source for agricultural crops. When determining the rate of $\mathrm{N}$ fertilizer application, the ability of animal manure compost to supply $\mathrm{N}$ should be considered from both economic and ecological perspectives. ${ }^{1,2}$ Manure compost releases $\mathrm{N}$ in agricultural soil much more slowly than does a chemical fertilizer, making it difficult to estimate the $\mathrm{N}$ supplied by manure compost, especially cattle manure compost. ${ }^{3-5}$ The major $\mathrm{N}$ form in compost is organic $\mathrm{N}$, which mainly consists of protein-like materials that are resistant to degradation by soil microbes. ${ }^{6-8}$ It has been suggested that the resistance of protein-like material present in soil organic matter to microbial attack is because it is complexed with soil components, such as humic substances..$^{9,10}$ It is possible that the same mechanism also contributes to the persistence of protein-like material in compost, ${ }^{7}$ although no direct evidence is available for both soil and compost. Therefore, characterizing the chemical form of the protein-like material in manure compost is critical to understand the stabilization mechanism of manure compost $\mathrm{N}$ in soil.

In elemental speciation studies, the separation of molecules with the element under study by HPLC, followed by detection using a sensitive element-specific method, such as inductively coupled plasma/mass spectrometry (ICP-MS), is a widely used technique. ${ }^{11}$ However, ICP-MS is not applicable to $\mathrm{N}$ detection. In contrast, chemiluminescent nitrogen detection (CLND) for

$\dagger$ To whom correspondence should be addressed.

E-mail: tmatunag@affrc.go.jp
HPLC is a unique $\mathrm{N}$ detection method that nebulizes the eluent from the HPLC column in a furnace at $1050^{\circ} \mathrm{C}$, and oxidizes $\mathrm{N}$ compounds (R-N) to $\mathrm{NO}$; it then converts the NO to excited $\mathrm{NO}_{2}$ with ozone, and detects emitted light. ${ }^{12}$ CLND was reported to be a useful quantitative HPLC detector for protein N. ${ }^{13}$ We also recently reported the molecular-weight distribution of extractable soil protein-like material using size-exclusion (SE)-HPLC/CLND. ${ }^{14}$ In the present study, to characterize the organic $\mathrm{N}$ in cattle manure compost, while focusing on the relationship between protein-like material and humic substances in the compost, after hot-water extracts of the compost were separated by SE-HPLC, N was detected by CLND, and humic acid-like substances were detected by absorption at $420 \mathrm{~nm} \cdot{ }^{15,16}$

\section{Experimental}

\section{Cattle manure compost}

The ${ }^{15} \mathrm{~N}$-labeled cattle manure compost used in this study was produced at the National Institute of Livestock and Grassland Sciences in 2003, as described previously. ${ }^{17}$ In brief, 2 adult dairy cows were fed ${ }^{15} \mathrm{~N}$-labeled orchard grass silage (first cut, 6.2 atom\% ${ }^{15} \mathrm{~N}$; second cut, 4.0 atom $\%{ }^{15} \mathrm{~N}$ ), and the dried feces and concentrated urine were mixed and composted in an air sucking composter for 4 weeks to obtain $150 \mathrm{~kg}$ fresh weight of cattle manure compost containing $21.3 \mathrm{~g} \mathrm{~N} / \mathrm{kg}$ dry weight $(3.95$ atom $\left.\%{ }^{15} \mathrm{~N}\right)$. The cattle manure compost was freeze-dried and pulverized. To extract the organic $\mathrm{N}$ fraction, the compost sample was suspended in deionized water at a ratio of 1:20 $(\mathrm{w} / \mathrm{v})$, heated for $16 \mathrm{~h}$ at $80^{\circ} \mathrm{C},{ }^{18,19}$ and then centrifuged to yield a dark-brown supernatant that was used as a hot-water compost 
extract.

Solid-state ${ }^{15} \mathrm{~N}$ nuclear magnetic resonance (NMR) measurements The ${ }^{15} \mathrm{~N}$ cross polarization/magic angle spinning (CP/MAS) NMR spectra of the freeze-dried cattle manure compost and its hot-water extract were recorded on a Agilent/Varian/ Chemagnetics Infinity 300 spectrometer (Fort Collins, CO), operating at resonance frequencies of $30 \mathrm{MHz}$, and equipped with a $4.0-\mathrm{mm}$ MAS probe operating at a spin rate of $10 \mathrm{kHz}$. A contact time of $1 \mathrm{~ms}$, a $\pi / 2{ }^{1} \mathrm{H}$-pulse width of $5 \mu \mathrm{S}$, and a repetition time of $3 \mathrm{~s}$ were used. Chemical shifts were referenced to $18 \mathrm{ppm}$ for ammonium chloride $\left(10.5\right.$ atom $\left.\%{ }^{15} \mathrm{~N}\right)$.

\section{SE-HPLC/CLND analysis}

To obtain the acid-insoluble fraction of the compost extract, $25 \mu \mathrm{L}$ of extract was diluted with $425 \mu \mathrm{L}$ of deionized water and acidified with $50 \mu \mathrm{L}$ of $1 \mathrm{M} \mathrm{HCl}$. After left standing for at least $1 \mathrm{~h}$, centrifugation separated the mixture into a precipitate, an acid-insoluble fraction, and a supernatant (acid-soluble fraction). The acid-insoluble fraction was dissolved in $210 \mu \mathrm{L}$ of acetic acid buffer (1 $\mathrm{M} \mathrm{CH}_{3} \mathrm{COOH}: 1 \mathrm{M} \mathrm{NaOH}, 1.1: 1.0$, v/v) and diluted with $290 \mu \mathrm{L}$ of deionized water. The acid-soluble and acid-insoluble fractions, as well as whole compost extract diluted 1:20 with deionized water $(\sim 30 \mathrm{mg} \mathrm{N} / \mathrm{L})$, were subjected to HPLC analysis.

For the alkali treatment, the acid-insoluble fraction from $25 \mu \mathrm{L}$ of compost extract was dissolved in $100 \mu \mathrm{L}$ of $1 \mathrm{M}$ $\mathrm{NaOH}$ and treated under 3 different conditions $\left(16 \mathrm{~h}\right.$ at $30^{\circ} \mathrm{C}$, $1 \mathrm{~h}$ at $100^{\circ} \mathrm{C}$, and $16 \mathrm{~h}$ at $100^{\circ} \mathrm{C}$ ), and then neutralized with $110 \mu \mathrm{L}$ of $1 \mathrm{M} \mathrm{CH}_{3} \mathrm{COOH}$, diluted with $290 \mu \mathrm{L}$ of deionized water, and separated by HPLC.

In the laccase treatment experiment, the acid-insoluble fraction prepared from $100 \mu \mathrm{L}$ of compost extract was dissolved in $1000 \mu \mathrm{L}$ of acetic acid buffer $\left(1 \mathrm{M} \mathrm{CH}_{3} \mathrm{COOH}: 1 \mathrm{M} \mathrm{NaOH}\right.$, 1.1:1.0, v/v). Two hundred microliters of the acid-insoluble fraction were diluted with $195 \mu \mathrm{L}$ of deionized water, and then $5 \mu \mathrm{L}$ of a laccase solution $\left(2 \mathrm{mg} / 500 \mu \mathrm{L}\right.$ in $\left.\mathrm{H}_{2} \mathrm{O}\right)$ was added, incubated overnight at $35^{\circ} \mathrm{C}$, and separated by HPLC. Two different laccase enzymes were used (SIGMA 75117 and SIGMA 51639).

Prepared samples were subjected to SE-HPLC. The HPLC system comprised a pump (PU-2080, JASCO, Tokyo, Japan), an autosampler (JASCO AS-2055i) with a chemiluminescent $\mathrm{N}$ detector (ANTEK 8060, PAC, USA), an ultraviolet/visible (UV/VIS) detector (JASCO UV-2070, VIS $420 \mathrm{~nm}$ ), a fluorescence detector (FLD; RF-10AxL, Shimadzu, Kyoto, Japan; $\lambda_{\mathrm{ex}}=340 \mathrm{~nm}, \lambda_{\mathrm{em}}=440 \mathrm{~nm}$ ), and a refractive-index detector (RID, Shimadzu RID-10A). The column used was a Diol-200 column $(8 \times 300 \mathrm{~mm}$; YMC Co., Kyoto, Japan $)$. The eluent was a $50 \mathrm{mM}$ sodium acetate/acetic acid buffer ( $\mathrm{pH} 7)$. The flow rate was $1.0 \mathrm{~mL} / \mathrm{min}$; at the outlet of the column, the eluent was split such that approximately $250 \mu \mathrm{L} / \mathrm{min}$ was directed to the CLND detector, and the remaining eluent was directed to the UV/VIS detector, fluorescence detector, and refractive index detector, which were connected in series. The CLND detector conditions were as follows: argon, $50 \mathrm{~mL} / \mathrm{min}$; oxygen, $250 \mathrm{~mL} / \mathrm{min}$; ozone, $25 \mathrm{~mL} / \mathrm{min}$; oven temperature, $1050^{\circ} \mathrm{C}$. The sample volume injected was $50 \mu \mathrm{L}$.

\section{Determinative analysis}

The total $\mathrm{N}$ concentrations in the compost extract and its acid insoluble fraction were determined by the HPLC/CLND system described above using a flow-injection mode. The amino acid $\mathrm{N}$ concentration in the compost extract was obtained by reversed-phase HPLC analysis after hydrochloric acid hydrolysis

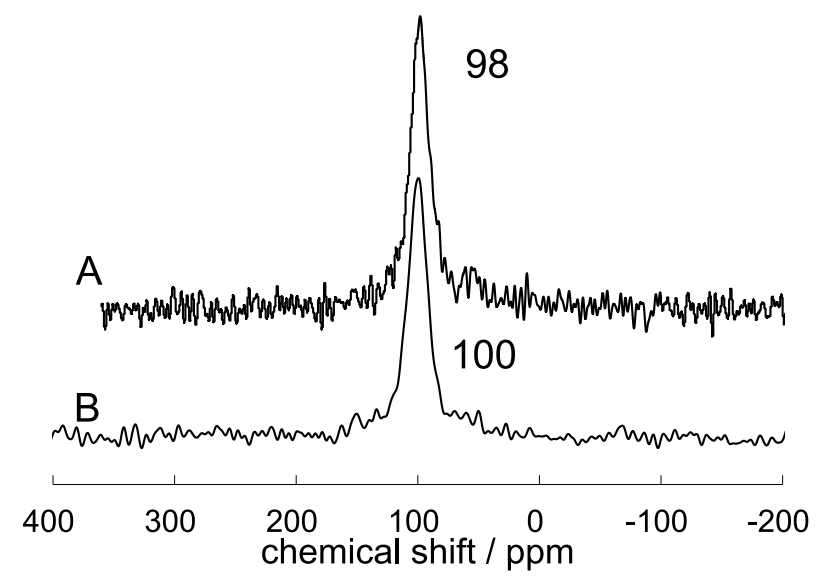

Fig. $1{ }^{15} \mathrm{~N} \mathrm{CP} / \mathrm{MAS}$ NMR spectra of (A) cattle manure compost and (B) its hot-water extract. Total scans: A, 57600; B, 57088.

and precolumn derivatization with o-phthaldialdehyde, as described previously. ${ }^{14}$ The concentrations of total organic carbon (TOC) and $\mathrm{N}$ in the acid insoluble fraction were measured by a TOC/TN analyzer (Shimadzu TOC-L/TNM-L) to calculate the $\mathrm{C} / \mathrm{N}$ ratio.

\section{Results and Discussion}

In the ${ }^{15} \mathrm{~N}$ CP/MAS NMR spectrum of the ${ }^{15} \mathrm{~N}$-enriched cattle manure compost (Fig. 1A), only a single peak assigned to amide was observed at $98 \mathrm{ppm}$. The ${ }^{15} \mathrm{~N}$ NMR spectrum of the hot-water extract, into which $60 \%$ of $\mathrm{N}$ in the compost was solubilized, also gave only an amide peak at 100 ppm (Fig. 1B), and approximately $30 \%$ of the $\mathrm{N}$ in the extract was recovered as amino acids after hydrochloric acid hydrolysis. These results indicate that the dominant organic $\mathrm{N}$ in both the compost and its hot-water extract is a protein-like substance, confirming the findings in a previous report by Tinoco et al. ${ }^{8}$

The molecular-weight distribution of the compost organic $\mathrm{N}$ was determined by SE-HPLC with CLND, VIS $420 \mathrm{~nm}$, fluorescence, and refractive index detection. The whole compost extract, and its acid-insoluble and acid-soluble fractions, which corresponded to the humic acid and fulvic acid-like fractions, ${ }^{20}$ respectively, were subjected to SE-HPLC. As shown in Fig. 2, the molecular weight of organic $\mathrm{N}$ in the whole compost varied widely. The compost organic $\mathrm{N}$ was clearly separated into the acid-insoluble fraction, with a higher molecular weight, and the acid-soluble fraction with a lower molecular weight. The total absorbance at $420 \mathrm{~nm}$ of the whole extract was mostly recovered in the acid-insoluble humic fraction, whereas the total fluorescence intensities were in the acid-soluble fulvic fraction. This result is in accordance with those of previous studies showing that fulvic acids are smaller than humic acids by flow field-flow fractionation, ${ }^{21}$ and that high-molecular-weight humic acids exhibit low fluorescence intensities. ${ }^{22}$ The CLND chromatogram pattern of the acid-insoluble fraction, which contained $70 \%$ of the total $\mathrm{N}$ in the compost extract, was very similar to the VIS $420 \mathrm{~nm}$ chromatogram pattern, suggesting that a molecule in the acid-insoluble fraction has both protein and humic acid-like moieties.

To clarify the relationship between the protein and humic acid-like moieties present in the acid-insoluble compost fraction, it was treated with alkali $(\mathrm{NaOH})$ or laccase, and was analyzed 

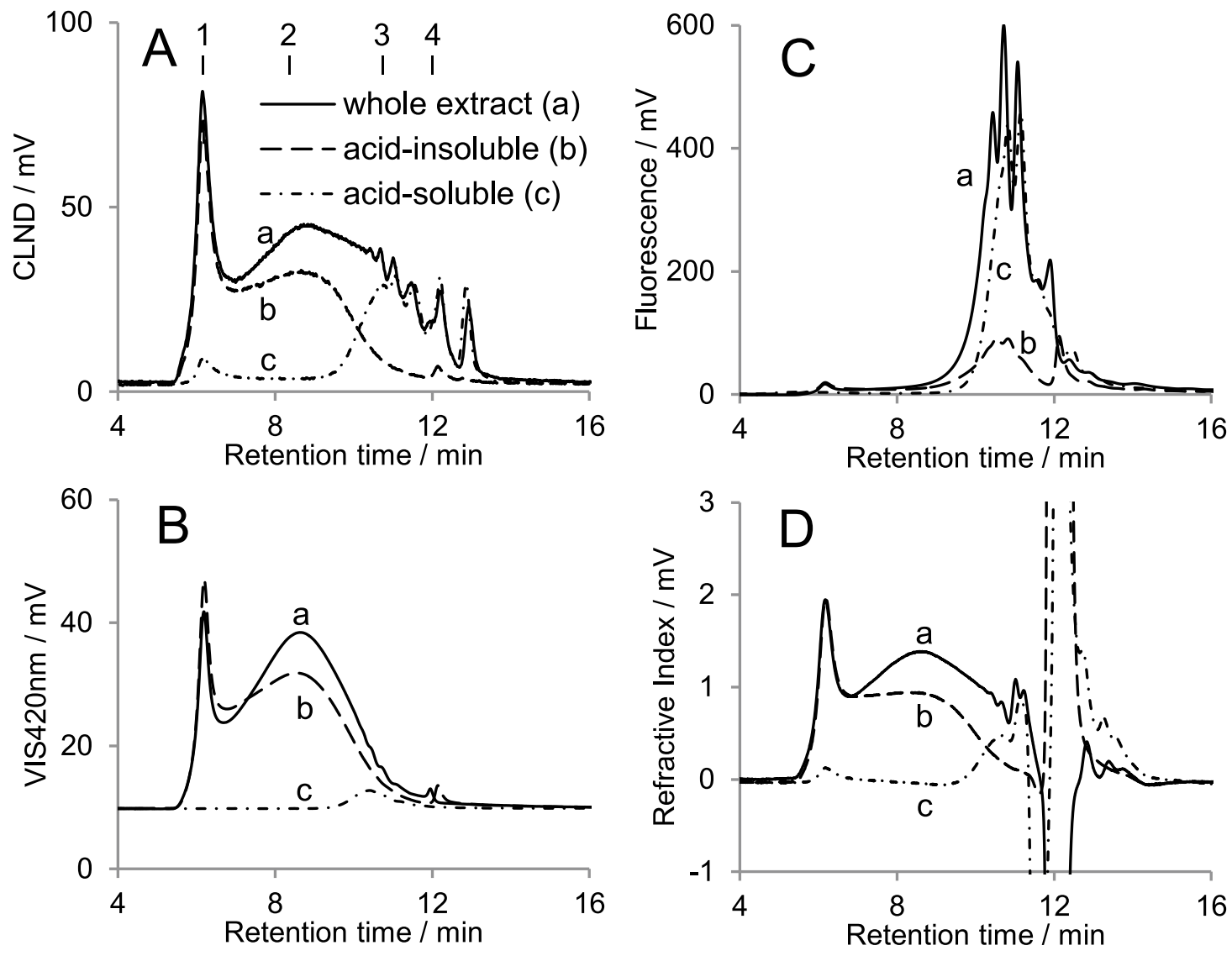

Fig. 2 SE-HPLC chromatograms of whole and acid-fractionated compost extracts. Detection: (A) CLND, (B) VIS $420 \mathrm{~nm}$, (C) FLD, (D) RID. Molecular weight standards: (1) thyloglobulin (670 kDa), (2) ovalbumin (42 kDa), (3) myoglobin (17 kDa), (4) vitamin B12 (1.35 kDa).

by SE-HPLC/CLND. In the alkali-treated acid-insoluble fraction, the molecular weight was reduced due to alkaline degradation of the proteins and humic acids ${ }^{23}$ (Fig. 3). In contrast, a laccase treatment increased the molecular weight of the acid-insoluble fraction (Fig. 4), probably due to polymerization of the humic substances. ${ }^{24}$ It should be noted that the changes in the molecular-weight distribution of the acid-insoluble fraction due to both the alkali and laccase treatments detected by CLND, coincided well with the changes in the absorption at $420 \mathrm{~nm}$. This result indicates that the organic $\mathrm{N}$ and humic substance moieties in the acid-insoluble fraction of cattle manure compost coexist in the same molecule. The $\mathrm{C} / \mathrm{N}$ ratio of the acid-insoluble fraction was measured to be 11. Assuming that the $\mathrm{C} / \mathrm{N}$ ratio of protein is $4,{ }^{10}$ one third of the organic matter in the acid-insoluble fraction is estimated to consist of a protein-like substance.

In agricultural soil, cattle manure compost supplies $\mathrm{N}$ at a much slower rate than chemical fertilizer. This slow $\mathrm{N}$ release is derived from the resistance of the protein-like $\mathrm{N}$ in the compost to microbial degradation; the reason for this stability is assumed to be because the protein-like $\mathrm{N}$ is complexed with other soil components, such as humic substances and clay minerals. . $^{7,910}$ In this study, using SE-HPLC with CLND and VIS $420 \mathrm{~nm}$, we clearly demonstrated that the polymers solubilized from cattle manure compost contain both protein and humic acid-like moieties in the same molecule. Many studies have been conducted on the coexistence of a protein moiety in humic substances since Suzuki revealed the presence of a certain amount of protein in humic acid samples in $1907 .{ }^{25}$
For example, Ladd and Brisbane ${ }^{26}$ reported: "Direct evidence for the occurrence of peptide bonds in soil humic acids has been obtained by showing that the proteolytic enzyme pronase releases $\alpha$-amino acids from each of 10 humic acids." However, in previous studies, including that by Ladd and Brisbane's, ${ }^{26}$ the possibility that protein and humic molecules exist separately in the acid-insoluble humic fraction was not excluded. In contrast, our study using SE-HPLC with CLND and absorption at $420 \mathrm{~nm}$ provided more direct evidence than that of previous reports. The next question to address is whether and how the protein/humic substance complex protects the protein moiety against bacterial attack. In preliminary experiments, we obtained data showing that a $24-\mathrm{h}$ protease (pronase, proteinase $\mathrm{K})$ treatment did not change the molecular-weight distribution of the acid-insoluble compost fraction, as measured by SE-HPLC/CLND. Further study using the SE-HPLC/CLND method is needed to better understand the effect of protein/humic substance complex formation on the stability of the compost and soil organic matter.

\section{Acknowledgements}

This work was supported in part by a grant from JSPS KAKENHI (No. 22580073). 

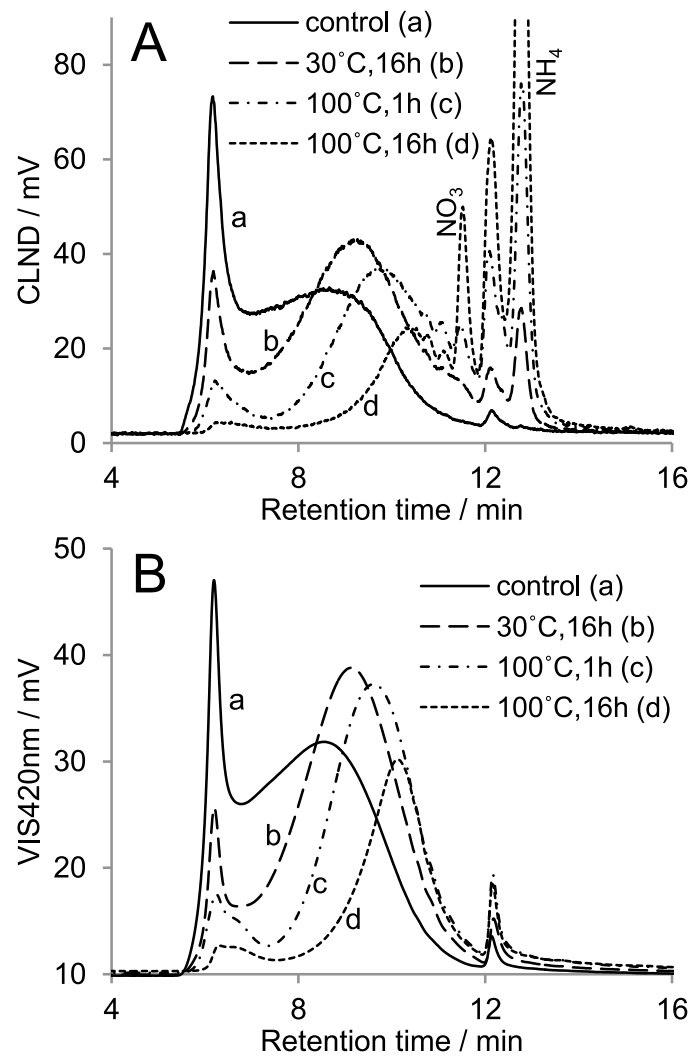

Fig. 3 SE-HPLC chromatograms of acid-insoluble fraction of compost extract treated with $\mathrm{NaOH}$. Detection: (A) CLND, and (B) VIS $420 \mathrm{~nm}$.

\section{References}

1. F. J. Larney, D. M. Sullivan, K. E. Buckley, and B. Eghball, Can. J. Soil Sci., 2006, 86, 597.

2. D. B. Beegle, K. A. Kelling, and M. A. Schmitt, "Nitrogen in Agricultural Systems", ed. J. S. Schepers and W. R. Raun, 2008, Chap. 21, American Society of Agronomy, Crop Science Society of America, Soil Science Society of America, Madison, 823.

3. J. Z. Castellanos and P. F. Pratt, Soil Sci. Soc. Am. J., 1981, $45,354$.

4. G. R. Muñoz, K. A. Kelling, K. E. Rylant, and J. Zhu, J. Environ. Qual., 2008, 37, 944.

5. T. Tanahashi and W. Oyanagi, Jpn. J. Soil Sci. Plant Nutr., 2011, 82, 244.

6. G. Almendros, R. Fründ, F. J. Gonzalez-Vila, K. M. Haider, H. Knicker, and H.-D. Lüdemann, FEBS Lett., 1991, 282, 119.

7. M. Pichler, H. Knicker, and I. Kögel-Knabner, Environ. Sci. Technol., 2000, 34, 4034.

8. P. Tinoco, G. Almendros, F. J. González-Vila, U. Lankes, and H.-D. Lüdemann, J. Agric. Food Chem., 2004, 52, 5412.

9. M. Moriizumi and T. Matsunaga, Jpn. J. Soil Sci. Plant Nutr., 2009, 80, 304.

10. H. Knicker, Soil Biol. Biochem., 2011, 43, 1118.

11. M. Popp, S. Hann, and G. Koellensperger, Anal. Chim. Acta, 2010, 668, 114.

12. W. L. Fitch, A. K. Szardenings, and E. M. Fujinari, Tetrahedron Lett., 1997, 38, 1689.
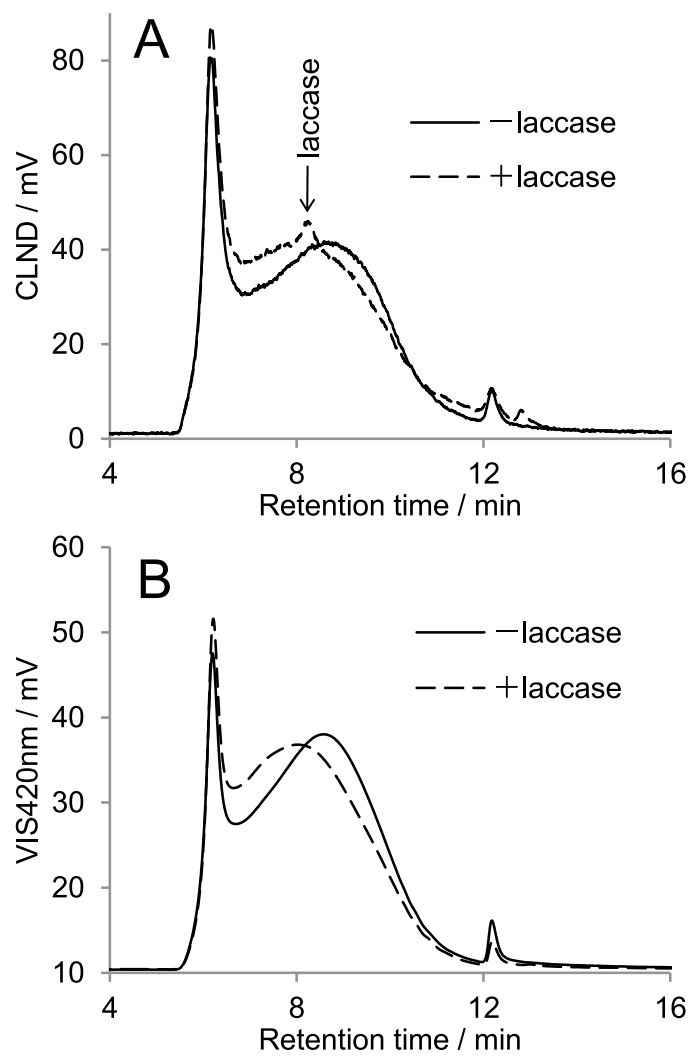

Fig. 4 SE-HPLC chromatograms of acid-insoluble fraction of compost extract treated with laccase (SIGMA 75117). A similar chromatogram was obtained for the sample treated with laccase (SIGMA 51639). Detection: (A) CLND, (B) VIS $420 \mathrm{~nm}$.

13. E. M. Fujinari and J. D. Manes, J. Chromatogr., A, 1997, 763,323

14. M. Moriizumi and T. Matsunaga, Soil Sci. Plant Nutr., 2011, 57, 185.

15. M. Nagayama, K. Goto, and T. Yotsuyanagi, Industrial Water, 1963, 61, 24

16. S. Tomita, Jpn. J. Limnol., 1993, 54, 97.

17. H. Matsunami and M. Hojito, Jpn. J. Soil Sci. Plant Nutr., 2005, 76, 153.

18. D. Curtin, C. E. Wright, M. H. Beare, and F. M. McCallum, Soil Sci. Soc. Am. J., 2006, 70, 1512.

19. I. Uezono, N. Kato, and M. Moriizumi, Jpn. J. Soil Sci. Plant Nutr., 2010, 81, 39.

20. R. S. Swift, "Methods of Soil Analysis. Part 3. Chemical Methods", ed. D. L. Sparks, A. L. Page, P. A. Helmke, R. H. Loeppert, P. N. Soltanpour, M. A. Tabatabai, C. T. Johnston, and M. E. Sumner, 1996, Chap. 35, Soil Science Society of America, American Society of Agronomy, Madison, 1011.

21. R. Beckett, Z. Jue, and J. C. Giddings, Environ. Sci. Technol., 1987, 21, 289.

22. N. Senesi, T. M. Miano, M. R. Provenzano, and G. Brunetti, Soil Sci., 1991, 152, 259.

23. J. A. Neyroud and M. Schnitzer, Geoderma, 1975, 13, 171.

24. A. G. Zavarzina, A. A. Leontievsky, L. A. Golovleva, and S. Ya. Trofimov, Soil Biol. Biochem., 2004, 36, 359.

25. S. Suzuki, Bull. Coll. Agric., Tokyo Imp. Univ., 1907, 7, 513.

26. J. N. Ladd and P. G. Brisbane, Aust. J. Soil Res., 1967, 5, 161. 